\title{
Model berbasis Sistem Kecerdasan Buatan yang Efektif: Analisis Kebijakan bagi Siswa Mengulang
}

\author{
Indra Prasetia ${ }^{\# 1}$, Muhammad Noor Hasan Siregar ${ }^{* 2}$, Rusmin Saragih ${ }^{-3}$ \\ ${ }^{\#}$ Universitas Muhammadiyah Sumatera Utara \\ Jl. Kapten Muchtar Basri No.3, Glugur Darat II, Kec. Medan Tim., Kota Medan, Sumatera Utara 20238 \\ 1indraprasetia@umsu.ac.id \\ *Universitas Graha Nusantara, Padangsidimpuan, Sumatera Utara \\ Jl. Dr. Sutomo, Wek I, Padangsidimpuan Utara, Kota Padang Sidempuan, Sumatera Utara 22718 \\ 2noor.siregaregmail.com \\ -STMIK Kaputama \\ Jl. Veteran No.4A, Tangsi, Kec. Binjai Kota, Kota Binjai, Sumatera Utara 20714 \\ 3evitha12014@gmail.com
}

\begin{abstract}
Abstrak- Pendidikan Sekolah Dasar (SD) sangat penting dalam memberikan keterampilan dasar yang dibutuhkan siswa untuk bertahan dalam mengikuti dan memahami kelaskelas pada jenjang di atasnya sehingga jika pondasi pendidikan SD kuat maka dapat meningkatkan kualitas pendidikan di Indonesia. Tujuan dari penelitian adalah membuat model arsitektur terbaik yang akan digunakan untuk melakukan peramalan pada jumlah siswa mengulang berdasarkan provinsi pada jenjnag Sekolah Dasar baik negeri dan swasta dengan model berbasis sistem kecerdasan buatan. Sumber data berasal dari data statistik pendidikan dengan url: http://statistik.data.kemdikbud.go.id/. Data terdiri dari 34 provinsi untuk tahun ajaran 2017/2017; 2017/2018; 2018/2019; 2019/2020. Metode solusi yang digunakan adalah back-propagation yang merupakan bagian dari sistem kecerdasan buatan dimana dalam menentukan model arsitektur terbaik dilakukan dengan menguji serangkaian arsitektur (2-5-1; 2-10-1; 2-15-1 dan 2-20-1) mengunakan fungsi aktivasi sigmoid dan parameter pendukung seperti performFcn $=$ MSE $;$ goal $=0.001 ;$ epochs $=10000 ; \mathrm{mc}=0.95$ dan $\mathrm{Ir}=0.1$. Hasil menunjukkan back-propagation dapat diterapkan untuk melakukan peramalan dengan sistem kecerdasan buatan dengan menghasilkan sebuah model arsitektur terbaik yakni 2-10-1 dengan MSE pelatihan adalah 0.00099299, koefisien korelasi $(R)$ pelatihan adalah 0.976972 pada epoch 81, MSE pengujian adalah 0.001325 , koefisien korelasi $(R)$ pengujian dengan akurasi $85 \%$. Fakta baru menyebutkan bahwa akurasi sangat tergantung terhadap banyaknya data. Selain harus memperhatikan MSE, epoch dan durasi waktu pelatihan. Diharapkan model arsitektur ini dapat membantu melakukan peramalan terhadap jumlah siswa mengulang pada jenjang Sekolah Dasar sehingga hasil dari peramalan dapat digunakan untuk membuat analisis kebijakan.
\end{abstract}

Kata kunci - Siswa mengulang, model arsitektur, JST, backpropagation, Indonesia, Sekolah Dasar

\section{Pendahuluan}

Sekolah Dasar (SD) merupakan salah satu bentuk satuan pendidikan dasar yang melandasi sekolah menengah atas sebagaimana diatur dalam UU No. 20 Tahun 2003 dan Jenis Pendidikan Pasal 17 (1) [1]. Pendidikan Sekolah Dasar di Indonesia masih sangat memprihatinkan. Padahal pendidikan SD sangat penting dalam memberikan keterampilan dasar yang dibutuhkan siswa untuk bertahan dalam mengikuti dan memahami kelas-kelas pada jenjang di atasnya. Jika memungkinkan untuk memperkuat pondasi pendidikan sejak SD maka beban pada jenjang pendidikan selanjutnya akan berkurang sehingga dapat meningkatkan kualitas pendidikan di Indonesia [2]. Pada prinsipnya pengulangan kelas dapat dilakukan sebagai proses belajar dimana hal ini dibenarkan dalam teori psikologi. Dengan mengadakan pengulangan maka daya tersebut akan berkembang. Daya itu merupakan daya yang melatih, daya mengamati, menanggapi, mengingat, mengkhayal, merasakan, dan berfikir [3]. Pada penelitian ingin dilakukan peramalam terhadap jumlah siswa mengulang berdasarkan provinsi untuk jenjang pendidikan Sekolah Dasar baik negeri dan swasta menggunakan sistem kecerdasan buatan. Hal ini dilakukan untuk dapat membuat kebijakan berdasarkan data peramalan yang dihasilkan. Data yang digunakan berasal dari data statistik pendidikan dengan url: http://statistik.data.kemdikbud.go.id/. Analisis peramalan perlu dilakukan mengingat kebanyakan metode statistik untuk peramalan yang digunakan pada saat ini memiliki kelemahan karena data yang digunakan untuk peramalan harus bersifat linear dan hasil tingkat akurasi yang kurang baik [4]. Beberapa metode statistik yang banyak digunakan adalah Exponential Smoothing (ES), SARIMA dan ARIMA) [5]-[7]. Untuk mengatasi kelemahan tersebut maka digunakan analisis peramalan dengan memanfaatkan teknik sistem kecerdasan buatan (artificial intelligence) [8]. Salah satu teknik yang 
digunakan adalah jaringan saraf tiruan (JST) [9] yang dapat menghasilkan hasil yang lebih baik melalui serangkaian pelatihan [10], [11]. Selain itu metode JST juga sangat baik digunakan pada data deret waktu yang bersifat tidak linear (nonlinear) yang mana ini tidak dapat diatasi oleh metode statistik [12]. Salah satu metode JST adalah backpropagation [13]-[16] yang dipilih untuk meramalkan jumlah siswa mengulang berdasarkan provinsi pada jenjang Sekolah Dasar. Hal ini sejalan dengan penelitian yang akan dikaji yakni dengan menemukan pola arsitektur terbaik dari serangkaian model back-propagation yang diuji dengan menggunakan parameter seperti learning rate dan arsitektur jaringan. Alasan digunakan metode ini karena menggunakan jaringan multilayer yang dapat meminimalkan error pada hasil [17] sehingga dapat, menghasilkan model akurasi terbaik [4]. Lebih lanjut penelitian terbaru tentang back-propagation adalah [18] tentang pengenalan wajah. Makalah ini membandingkan tiga algoritma yang berbeda dan menguji keakuratan algoritma tersebut dimana back-propagation menjadi algoritma terbaik dengan akurasi diatas $85 \%$. Selanjutnya penelitian yang dilakukan [19] tentang pemodelan pemakaian listrik. Makalah ini mengusulkan metode backpropagation untuk membuat model konsumsi listrik di kota Kendari Hasil penelitian menyebutkan metode ini dapat diterapkan dengan menghasilkan model arsitektur dengan 10 unit input layer dan 4 unit hidden layer dengan MSE terkecil 0,000145. Lebih lanjut, hasil penelitian ini diharapkan dapat membantu memberikan informasi tentang peramalan terhadap jumlah siswa mengulang pada periode berikutnya yang tidak dapat diatasi oleh metode statistik yang ada sehingga dapat digunakan untuk membuat analisis kebijakan.

\section{Metode Penelitian}

Pada tahapan ini dijelaskan secara singkat tentang data siswa mengulang, metode back-propaagtion beserta alur kerja yang dituangkan dalam narasi flowchat dan pengukuran hasil dari analisis peramalan jumlah siswa mengulang dengan algortima back-propagation.

\section{A. Data jumlah siswa mengulang}

Data yang digunakan adalah data dengan subjek jumlah siswa mengulang menurut tingkat pada tiap provinsi dimana penelitian ini fokus pada tingkat jenjang pendidikan Sekolah Dasar. Sumber data dari data statistik pendidikan (http://statistik.data.kemdikbud.go.id/). Data yang digunakan adalah data jenjang Sekolah Dasar pada tahun ajaran 2017/2017; 2017/2018; 2018/2019 dan 2019/2020. Data tersebut dapat dilihat pada Tabel 1-4 dan diplotkan pada Gambar 1. Adapun penelitian ini menggunakan bantuan software modeling MATLAB R2021a.

TABEL I

JUMLAH SISWA MENGULANG MENURUT PROVINSI (2016/2017)

\begin{tabular}{|l|c|c|r|r|r|r|}
\hline Provinsi & \multicolumn{7}{|c|}{ Tingkat / Grade } \\
\hline Province & I & \multicolumn{1}{|c|}{ II } & III & \multicolumn{1}{|c|}{ IV } & \multicolumn{1}{c|}{ V } & VI \\
\hline Prov. D.K.I Jakarta & 1,113 & 1,000 & 888 & 761 & 582 & 11 \\
\hline Prov. Jawa Barat & 9,155 & 4,095 & 3,008 & 1,642 & 1,316 & 68 \\
\hline
\end{tabular}

\begin{tabular}{|l|r|r|r|r|r|r|}
\hline Provinsi & \multicolumn{7}{|c|}{ Tingkat / Grade } \\
\hline Province & \multicolumn{1}{|c|}{ I } & \multicolumn{1}{|c|}{ II } & \multicolumn{1}{|c|}{ IV } & \multicolumn{1}{c|}{ V } & \multicolumn{1}{|c|}{ VI } \\
\hline Prov. Jawa Tengah & 19,870 & 11,626 & 10,233 & 6,981 & 4,403 & 54 \\
\hline Prov. D.I. Yogyakarta & 999 & 635 & 593 & 475 & 373 & 5 \\
\hline Prov. Jawa Timur & 13,055 & 5,708 & 4,132 & 2,589 & 1,743 & 67 \\
\hline Prov. Aceh & 2,032 & 1,138 & 968 & 542 & 311 & 17 \\
\hline Prov. Sumatera Utara & 7,486 & 3,725 & 2,804 & 1,652 & 1,243 & 170 \\
\hline Prov. Sumatera Barat & 6,619 & 4,203 & 4,108 & 3,315 & 2,416 & 48 \\
\hline Prov. Riau & 5,420 & 2,838 & 2,221 & 1,360 & 892 & 18 \\
\hline Prov. Jambi & 2,721 & 1,289 & 909 & 542 & 325 & 15 \\
\hline Prov. Sumatera Selatan & 6,393 & 3,384 & 2,798 & 1,539 & 979 & 47 \\
\hline Prov. Lampung & 5,385 & 2,420 & 1,848 & 1,041 & 589 & 14 \\
\hline Prov. Kalimantan Barat & 10,304 & 5,258 & 4,197 & 2,824 & 1,831 & 30 \\
\hline Prov. Kalimantan Tengah & 2,815 & 1,235 & 877 & 580 & 331 & 16 \\
\hline Prov. Kalimantan Selatan & 4,452 & 2,066 & 1,527 & 862 & 458 & 14 \\
\hline Prov. Kalimantan Timur & 1,709 & 1,415 & 1,051 & 593 & 437 & 6 \\
\hline Prov. Sulawesi Utara & 831 & 418 & 340 & 266 & 235 & 17 \\
\hline Prov. Sulawesi Tengah & 2,848 & 1,356 & 1,177 & 810 & 558 & 27 \\
\hline Prov. Sulawesi Selatan & 4,531 & 2,431 & 2,140 & 1,267 & 1,100 & 228 \\
\hline Prov. Sulawesi Tenggara & 2,000 & 1,168 & 1,213 & 847 & 679 & 128 \\
\hline Prov. Maluku & 2,177 & 784 & 634 & 400 & 248 & 30 \\
\hline Prov. Bali & 1,000 & 562 & 392 & 168 & 69 & 2 \\
\hline Prov. NTB & 2,789 & 1,287 & 1,112 & 618 & 503 & 52 \\
\hline Prov. NTT & 12,548 & 6,618 & 5,662 & 3,876 & 2,572 & 52 \\
\hline Prov. Papua & 4,866 & 2,178 & 2,025 & 1,363 & 1,511 & 227 \\
\hline Prov. Bengkulu & 1,802 & 898 & 717 & 459 & 349 & 0 \\
\hline Prov. Maluku Utara & 1,228 & 508 & 437 & 288 & 238 & 30 \\
\hline Prov. Banten & 5,116 & 2,411 & 1,677 & 724 & 467 & 11 \\
\hline Prov. Kep.Bangka & 1,540 & 940 & 978 & 633 & 451 & 0 \\
\hline Prov. Gorontalo & 1,725 & 978 & 759 & 543 & 461 & 38 \\
\hline Prov. Kepulauan Riau & 1,019 & 573 & 456 & 358 & 214 & 1 \\
\hline Prov. Papua Barat & 1,860 & 841 & 745 & 451 & 248 & 25 \\
\hline Prov. Sulawesi Barat & 871 & 555 & 545 & 317 & 249 & 17 \\
\hline Prov. Kalimantan Utara & 693 & 275 & 225 & 123 & 114 & 2 \\
\hline
\end{tabular}

TABEL II

JUMLAH SISWA MENGULANG MENURUT PROVINSI (2017/2018)

\begin{tabular}{|l|r|r|r|r|r|r|}
\hline Provinsi & \multicolumn{7}{|c|}{ Tingkat / Grade } \\
\hline Province & \multicolumn{1}{|c|}{ I } & \multicolumn{1}{|c|}{ II } & \multicolumn{1}{|c|}{ III } & \multicolumn{1}{|c|}{ IV } & \multicolumn{1}{|c|}{ V } & VI \\
\hline Prov. D.K.I Jakarta & 1,229 & 960 & 867 & 702 & 620 & 8 \\
\hline Prov. Jawa Barat & 8,720 & 3,645 & 2,439 & 1,499 & 1,338 & 22 \\
\hline Prov. Jawa Tengah & 20,865 & 11,868 & 9,827 & 6,592 & 4,256 & 32 \\
\hline Prov. D.I. Yogyakarta & 898 & 602 & 521 & 321 & 280 & 2 \\
\hline Prov. Jawa Timur & 13,481 & 5,224 & 3,812 & 2,463 & 1,929 & 62 \\
\hline Prov. Aceh & 2,400 & 993 & 906 & 578 & 344 & 25 \\
\hline Prov. Sumatera Utara & 7,522 & 3,342 & 2,483 & 1,526 & 1,099 & 150 \\
\hline Prov. Sumatera Barat & 6,964 & 4,280 & 4,168 & 3,339 & 2,365 & 21 \\
\hline Prov. Riau & 5,423 & 2,672 & 2,124 & 1,241 & 839 & 21 \\
\hline Prov. Jambi & 2,827 & 1,187 & 950 & 470 & 329 & 15 \\
\hline Prov. Sumatera Selatan & 7,470 & 3,433 & 2,769 & 1,625 & 1,047 & 39 \\
\hline Prov. Lampung & 5,460 & 2,440 & 1,815 & 994 & 688 & 10 \\
\hline Prov. Kalimantan Barat & 11,056 & 5,444 & 4,336 & 2,785 & 2,037 & 26 \\
\hline Prov. Kalimantan Tengah & 3,310 & 1,309 & 1,056 & 660 & 360 & 16 \\
\hline Prov. Kalimantan Selatan & 4,638 & 2,046 & 1,532 & 740 & 394 & 14 \\
\hline Prov. Kalimantan Timur & 2,883 & 1,253 & 999 & 583 & 340 & 5 \\
\hline Prov. Sulawesi Utara & 1,179 & 485 & 429 & 259 & 272 & 10 \\
\hline Prov. Sulawesi Tengah & 3,138 & 1,459 & 1,276 & 758 & 619 & 51 \\
\hline Prov. Sulawesi Selatan & 4,912 & 2,186 & 1,941 & 1,162 & 1,064 & 181 \\
\hline Prov. Sulawesi Tenggara & 2,093 & 1,042 & 1,067 & 837 & 613 & 142 \\
\hline Prov. Maluku & 2,559 & 931 & 689 & 467 & 332 & 41 \\
\hline Prov. Bali & 991 & 463 & 337 & 131 & 62 & 1 \\
\hline Prov. NTB & 3,439 & 1,402 & 986 & 647 & 551 & 60 \\
\hline Prov. NTT & 14,010 & 6,183 & 5,230 & 3,871 & 2,770 & 59 \\
\hline Prov. Papua & 6,446 & 2,725 & 2,612 & 1,903 & 2,450 & 395 \\
\hline Prov. Bengkulu & 1,817 & 882 & 722 & 441 & 350 & 7 \\
\hline Prov. Maluku Utara & 1,413 & 451 & 385 & 269 & 217 & 46 \\
\hline Prov. Banten & 4,967 & 2,052 & 1,485 & 589 & 408 & 23 \\
\hline Prov. Kep. Bangka & 1,712 & 950 & 896 & 689 & 409 & 1 \\
\hline Prov. Gorontalo & 1,984 & 899 & 817 & 577 & 531 & 51 \\
\hline Prov. Kepulauan Riau & 1,105 & 554 & 478 & 372 & 210 & 5 \\
\hline Prov. Papua Barat & 2,641 & 1,044 & 986 & 665 & 590 & 61 \\
\hline Prov. Sulawesi Barat & 1,107 & 566 & 557 & 368 & 318 & 32 \\
\hline Prov. Kalimantan Utara & 834 & 293 & 215 & 163 & 109 & 6 \\
\hline
\end{tabular}

TABEL III

JUMLAH SISWA MENGULANG MENURUT PROVINSI (2018/2019)

\begin{tabular}{|l|r|r|r|r|r|r|}
\hline Provinsi & \multicolumn{7}{|c|}{ Tingkat / Grade } \\
\hline Province & \multicolumn{1}{|c|}{ I } & \multicolumn{1}{|c|}{ II } & \multicolumn{1}{c|}{ II } & \multicolumn{1}{|c|}{ IV } & \multicolumn{1}{|c|}{ V } & \multicolumn{1}{|c|}{ VI } \\
\hline Prov. D.K.I Jakarta & 1,550 & 903 & 902 & 663 & 743 & 35 \\
\hline Prov. Jawa Barat & 7,516 & 3,454 & 2,363 & 1,347 & 1,647 & 56 \\
\hline Prov. Jawa Tengah & 18,413 & 10,693 & 8,757 & 5,532 & 3,820 & 29 \\
\hline Prov. D.I. Yogyakarta & 741 & 539 & 465 & 281 & 259 & 3 \\
\hline Prov. Jawa Timur & 11,314 & 4,559 & 3,145 & 1,965 & 1,942 & 63 \\
\hline Prov. Aceh & 2,002 & 926 & 776 & 525 & 485 & 32 \\
\hline Prov. Sumatera Utara & 6,558 & 3,116 & 2,476 & 1,392 & 1,244 & 101 \\
\hline Prov. Sumatera Barat & 6,770 & 4,193 & 3,830 & 2,732 & 2,193 & 7 \\
\hline Prov. Riau & 5,504 & 2,554 & 2,029 & 1,114 & 952 & 22 \\
\hline Prov. Jambi & 2,801 & 1,096 & 864 & 471 & 348 & 20 \\
\hline
\end{tabular}




\begin{tabular}{|c|c|c|c|c|c|c|}
\hline \multirow{2}{*}{$\begin{array}{l}\text { Provinsi } \\
\text { Province }\end{array}$} & \multicolumn{6}{|c|}{ Tingkat / Grade } \\
\hline & I & II & III & IV & $\mathbf{V}$ & VI \\
\hline Prov. Sumatera Selatan & 7,060 & 3,696 & 2,902 & 1,616 & 1,269 & 47 \\
\hline Prov. Lampung & 4,686 & 2,232 & 1,800 & 821 & 701 & 28 \\
\hline Prov. Kalimantan Barat & 10,339 & 4,927 & 3,924 & 2,559 & 1,839 & 52 \\
\hline Prov. Kalimantan Tengah & 3,139 & 1,270 & 977 & 455 & 386 & 25 \\
\hline Prov. Kalimantan Selatan & 4,473 & 1,810 & 1,271 & 554 & 377 & 6 \\
\hline Prov. Kalimantan Timur & 2,409 & 1,183 & 861 & 506 & 387 & 14 \\
\hline Prov. Sulawesi Utara & 1,243 & 425 & 467 & 324 & 420 & 14 \\
\hline Prov. Sulawesi Tengah & 2,824 & 1,194 & 1,000 & 563 & 573 & 30 \\
\hline Prov. Sulawesi Selatan & 4,007 & 1,918 & 1,635 & 908 & 1,145 & 151 \\
\hline Prov. Sulawesi Tenggara & 1,600 & 987 & 977 & 695 & 875 & 111 \\
\hline Prov. Maluku & 2,148 & 744 & 532 & 370 & 426 & 14 \\
\hline Prov. Bali & 795 & 412 & 287 & 114 & 69 & 6 \\
\hline Prov. NTB & 2,998 & 1,125 & 917 & 522 & 521 & 19 \\
\hline Prov. NTT & 12,416 & 5,669 & 4,701 & 3,500 & 2,876 & 73 \\
\hline Prov. Papua & 6,623 & 3,279 & 2,621 & 2,168 & 3,507 & 308 \\
\hline Prov. Bengkulu & 1,725 & 916 & 649 & 386 & 352 & 17 \\
\hline Prov. Maluku Utara & 1,362 & 509 & 445 & 282 & 472 & 81 \\
\hline Prov. Banten & 4,135 & 1,837 & 1,311 & 570 & 583 & 16 \\
\hline Prov. Kep. Bangka Belitung & 1,678 & 906 & 874 & 590 & 468 & 2 \\
\hline Prov. Gorontalo & 1,660 & 717 & 671 & 466 & 453 & 18 \\
\hline Prov. Kepulauan Riau & 1,035 & 522 & 455 & 288 & 219 & 1 \\
\hline Prov. Papua Barat & 2,421 & 1,084 & 980 & 827 & 1,081 & 37 \\
\hline Prov. Sulawesi Barat & 944 & 496 & 511 & 324 & 375 & 26 \\
\hline Prov. Kalimantan Utara & 619 & 254 & 174 & 119 & 74 & 1 \\
\hline
\end{tabular}

TABEL IV

JUMLAH SISWA MENGULANG MENURUT PROVINSI (2019/2020)

\begin{tabular}{|l|r|r|r|r|r|r|}
\hline Provinsi & \multicolumn{7}{|c|}{ Tingkat / Grade } \\
\hline Province & \multicolumn{1}{|c|}{ I } & \multicolumn{1}{|c|}{ III } & \multicolumn{1}{|c|}{ IV } & \multicolumn{1}{|c|}{ V } & VI \\
\hline Prov. D.K.I Jakarta & 1,426 & 780 & 655 & 571 & 705 & 6 \\
\hline Prov. Jawa Barat & 6,201 & 2,572 & 1,906 & 1,153 & 1,582 & 12 \\
\hline Prov. Jawa Tengah & 15,085 & 8,240 & 6,322 & 3,711 & 2,813 & 21 \\
\hline Prov. D.I. Yogyakarta & 544 & 414 & 350 & 274 & 195 & 1 \\
\hline Prov. Jawa Timur & 8,348 & 3,145 & 2,309 & 1,627 & 1,721 & 4 \\
\hline Prov. Aceh & 1,794 & 757 & 648 & 432 & 433 & 5 \\
\hline Prov. Sumatera Utara & 5,597 & 2,649 & 2,030 & 1,147 & 1,508 & 14 \\
\hline Prov. Sumatera Barat & 5,745 & 3,265 & 2,911 & 2,297 & 1,637 & 6 \\
\hline Prov. Riau & 4,984 & 2,102 & 1,545 & 977 & 878 & 1 \\
\hline Prov. Jambi & 2,553 & 887 & 589 & 310 & 369 & 3 \\
\hline Prov. Sumatera Selatan & 6,004 & 2,743 & 2,174 & 1,196 & 1,426 & 11 \\
\hline Prov. Lampung & 3,666 & 1,819 & 1,249 & 717 & 607 & 13 \\
\hline Prov. Kalimantan Barat & 9,416 & 4,322 & 3,173 & 2,018 & 1,833 & 6 \\
\hline Prov. Kalimantan Tengah & 2,647 & 1,071 & 777 & 492 & 428 & 32 \\
\hline Prov. Kalimantan Selatan & 3,884 & 1469 & 1,076 & 461 & 313 & 0 \\
\hline Prov. Kalimantan Timur & 1,951 & 887 & 685 & 400 & 312 & 5 \\
\hline Prov. Sulawesi Utara & 897 & 457 & 359 & 228 & 466 & 0 \\
\hline Prov. Sulawesi Tengah & 2,061 & 963 & 774 & 387 & 568 & 13 \\
\hline Prov. Sulawesi Selatan & 3,519 & 1,520 & 1,334 & 809 & 920 & 39 \\
\hline Prov. Sulawesi Tenggara & 1,295 & 671 & 749 & 520 & 779 & 18 \\
\hline Prov. Maluku & 1,828 & 569 & 459 & 308 & 557 & 2 \\
\hline Prov. Bali & 627 & 321 & 196 & 84 & 50 & 0 \\
\hline Prov. NTB & 2,214 & 816 & 768 & 423 & 638 & 1 \\
\hline Prov. NTT & 10,301 & 4,124 & 3,441 & 2,587 & 2,387 & 13 \\
\hline Prov. Papua & 5,214 & 2,208 & 2,143 & 1,949 & 4,038 & 99 \\
\hline Prov. Bengkulu & 1,554 & 709 & 521 & 379 & 358 & 1 \\
\hline Prov. Maluku Utara & 1,035 & 399 & 260 & 192 & 452 & 19 \\
\hline Prov. Banten & 3,327 & 1,415 & 957 & 481 & 643 & 8 \\
\hline Prov. Kep.Bangka Belitung & 1,463 & 758 & 611 & 450 & 284 & 1 \\
\hline Prov. Gorontalo & 1455 & 583 & 440 & 352 & 338 & 5 \\
\hline Prov. Kepulauan Riau & 913 & 465 & 365 & 273 & 276 & 1 \\
\hline Prov. Papua Barat & 2,134 & 869 & 750 & 600 & 1,360 & 20 \\
\hline Prov. Sulawesi Barat & 785 & 442 & 448 & 251 & 369 & 7 \\
\hline Prov. Kalimantan Utara & 546 & 192 & 129 & 69 & 72 & 0 \\
\hline
\end{tabular}

Pada Tabel 1-4 data akan diolah dengan menjumlahkan total keseluruhan dari tingkat I-VI berdasarkan provinsi. Data tabel jumlah siswa mengulang berdasarkan privinsi yang sudah diolah dapat dilihat pada Tabel 5.

TABEL V

JUMLAH SISWA MENGULANG MENURUT PROVINSI

\begin{tabular}{|l|r|r|r|r|}
\hline \multicolumn{1}{|c|}{ Provinsi } & $\mathbf{2 0 1 6 - 2 0 1 7}$ & $\mathbf{2 0 1 7 - 2 0 1 8}$ & $\mathbf{2 0 1 8 - 2 0 1 9}$ & $\mathbf{2 0 1 9 - 2 0 2 0}$ \\
\hline Prov. D.K.I Jakarta & 4355 & 4386 & 4796 & 4143 \\
\hline Prov. Jawa Barat & 19284 & 17663 & 16383 & 13426 \\
\hline Prov. Jawa Tengah & 53167 & 53440 & 47244 & 36192 \\
\hline Prov. D.I. Yogyakarta & 3080 & 2624 & 2288 & 1778 \\
\hline Prov. Jawa Timur & 27294 & 26971 & 22988 & 17154 \\
\hline Prov. Aceh & 5008 & 5246 & 4746 & 4069 \\
\hline Prov. Sumatera Utara & 17080 & 16122 & 14887 & 12945 \\
\hline Prov. Sumatera Barat & 20709 & 21137 & 19725 & 15861 \\
\hline Prov. Riau & 12749 & 12320 & 12175 & 10487 \\
\hline Prov. Jambi & 5801 & 5778 & 5600 & 4711 \\
\hline Prov. Sumatera Selatan & 15140 & 16383 & 16590 & 13554 \\
\hline
\end{tabular}

\begin{tabular}{|l|r|r|r|r|}
\hline \multicolumn{1}{|c|}{ Provinsi } & 2016-2017 & 2017-2018 & 2018-2019 & 2019-2020 \\
\hline Prov. Lampung & 11297 & 11407 & 10268 & 8071 \\
\hline Prov. Kalimantan Barat & 24444 & 25684 & 23640 & 20768 \\
\hline Prov. Kalimantan Tengah & 5854 & 6711 & 6252 & 5447 \\
\hline Prov. Kalimantan Selatan & 9379 & 9364 & 8491 & 7203 \\
\hline Prov. Kalimantan Timur & 5211 & 6063 & 5360 & 4240 \\
\hline Prov. Sulawesi Utara & 2107 & 2634 & 2893 & 2407 \\
\hline Prov. Sulawesi Tengah & 6776 & 7301 & 6184 & 4766 \\
\hline Prov. Sulawesi Selatan & 11697 & 11446 & 9764 & 8141 \\
\hline Prov. Sulawesi Tenggara & 6035 & 5794 & 5245 & 4032 \\
\hline Prov. Maluku & 4273 & 5019 & 4234 & 3723 \\
\hline Prov. Bali & 2193 & 1985 & 1683 & 1278 \\
\hline Prov. NTB & 6361 & 7085 & 6102 & 4860 \\
\hline Prov. NTT & 31328 & 32123 & 29235 & 22853 \\
\hline Prov. Papua & 12170 & 16531 & 18506 & 15651 \\
\hline Prov. Bengkulu & 4225 & 4219 & 4045 & 3522 \\
\hline Prov. Maluku Utara & 2729 & 2781 & 3151 & 2357 \\
\hline Prov. Banten & 10406 & 9524 & 8452 & 6831 \\
\hline Prov. Kep. Bangka & 4542 & 4657 & 4518 & 3567 \\
\hline Prov. Gorontalo & 4504 & 4859 & 3985 & 3173 \\
\hline Prov. Kepulauan Riau & 2621 & 2724 & 2520 & 2293 \\
\hline Prov. Papua Barat & 4170 & 5987 & 6430 & 5733 \\
\hline Prov. Sulawesi Barat & 2554 & 2948 & 2676 & 2302 \\
\hline Prov. Kalimantan Utara & 1432 & 1620 & 1241 & 1008 \\
\hline
\end{tabular}

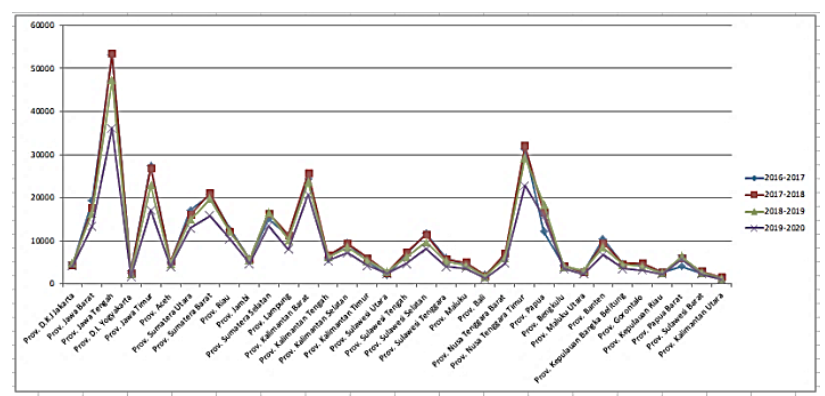

Gambar. 1 Plot data jumlah siswa mengulang berdasarkan provinsi pada jenjang Sekolah Dasar

Sebelum proses peramalan dilakukan, maka proses normalisasi jumlah data siswa mengulang dilakukan dengan mengubah nilai kedalam ordo [0-1]. Hal ini bertujuan mempercepat proses pelatihan algortima backpropagation tanpa mengurangi nilai data sebenarnya dengan menggunakan fungsi aktivasi yang digunakan adalah sigmoid. Berikut formula yang digunakan untuk menormalisasikan data.

$X^{\prime}=\frac{0,8(X-b)}{(a-b)}+0,1$

Dimana nilai $\mathrm{X}^{1}$ merupakan nilai hasil normalisasi data, $\mathrm{X}$ merupakan nilai yang akan dinormalisasi, a merupakan nilai maksimum dari seluruh data penelitian, bmerupakan nilai minimum dari seluruh data penelitian, 0.8 dan 0.1 adalah bilangan ketetapan (konstanta).

TABEL VI

DATA NORMALISASI

\begin{tabular}{|l|r|r|r|r|}
\hline \multicolumn{1}{|c|}{ Provinsi } & $\mathbf{2 0 1 6 - 2 0 1 7}$ & $\mathbf{2 0 1 7 - 2 0 1 8}$ & $\mathbf{2 0 1 8 - 2 0 1 9}$ & $\mathbf{2 0 1 9 - 2 0 2 0}$ \\
\hline Prov. D.K.I Jakarta & 0.1511 & 0.1515 & 0.1578 & 0.1478 \\
\hline Prov. Jawa Barat & 0.3789 & 0.3541 & 0.3346 & 0.2895 \\
\hline Prov. Jawa Tengah & 0.8958 & 0.9000 & 0.8055 & 0.6368 \\
\hline Prov. D.I. Yogyakarta & 0.1316 & 0.1247 & 0.1195 & 0.1117 \\
\hline Prov. Jawa Timur & 0.5011 & 0.4961 & 0.4354 & 0.3464 \\
\hline Prov. Aceh & 0.1610 & 0.1647 & 0.1570 & 0.1467 \\
\hline Prov. Sumatera Utara & 0.3452 & 0.3306 & 0.3118 & 0.2821 \\
\hline Prov. Sumatera Barat & 0.4006 & 0.4071 & 0.3856 & 0.3266 \\
\hline Prov. Riau & 0.2791 & 0.2726 & 0.2704 & 0.2446 \\
\hline Prov. Jambi & 0.1731 & 0.1728 & 0.1701 & 0.1565 \\
\hline Prov. Sumatera Selatan & 0.3156 & 0.3346 & 0.3377 & 0.2914 \\
\hline Prov. Lampung & 0.2570 & 0.2587 & 0.2413 & 0.2078 \\
\hline Prov. Kalimantan Barat & 0.4576 & 0.4765 & 0.4453 & 0.4015 \\
\hline Prov. Kalimantan Tengah & 0.1739 & 0.1870 & 0.1800 & 0.1677 \\
\hline
\end{tabular}




\begin{tabular}{|l|r|r|r|r|}
\hline \multicolumn{1}{|c|}{ Provinsi } & 2016-2017 & 2017-2018 & 2018-2019 & 2019-2020 \\
\hline Prov. Kalimantan Selatan & 0.2277 & 0.2275 & 0.2142 & 0.1945 \\
\hline Prov. Kalimantan Timur & 0.1641 & 0.1771 & 0.1664 & 0.1493 \\
\hline Prov. Sulawesi Utara & 0.1168 & 0.1248 & 0.1288 & 0.1213 \\
\hline Prov. Sulawesi Tengah & 0.1880 & 0.1960 & 0.1790 & 0.1573 \\
\hline Prov. Sulawesi Selatan & 0.2631 & 0.2593 & 0.2336 & 0.2088 \\
\hline Prov. Sulawesi Tenggara & 0.1767 & 0.1730 & 0.1646 & 0.1461 \\
\hline Prov. Maluku & 0.1498 & 0.1612 & 0.1492 & 0.1414 \\
\hline Prov. Bali & 0.1181 & 0.1149 & 0.1103 & 0.1041 \\
\hline Prov. NTB & 0.1817 & 0.1927 & 0.1777 & 0.1588 \\
\hline Prov. NTT & 0.5626 & 0.5747 & 0.5307 & 0.4333 \\
\hline Prov. Papua & 0.2703 & 0.3368 & 0.3670 & 0.3234 \\
\hline Prov. Bengkulu & 0.1491 & 0.1490 & 0.1463 & 0.1384 \\
\hline Prov. Maluku Utara & 0.1263 & 0.1271 & 0.1327 & 0.1206 \\
\hline Prov. Banten & 0.2434 & 0.2299 & 0.2136 & 0.1888 \\
\hline Prov. Kep. Bangka & 0.1539 & 0.1557 & 0.1536 & 0.1390 \\
\hline Prov. Gorontalo & 0.1533 & 0.1588 & 0.1454 & 0.1330 \\
\hline Prov. Kepulauan Riau & 0.1246 & 0.1262 & 0.1231 & 0.1196 \\
\hline Prov. Papua Barat & 0.1482 & 0.1760 & 0.1827 & 0.1721 \\
\hline Prov. Sulawesi Barat & 0.1236 & 0.1296 & 0.1255 & 0.1197 \\
\hline Prov. Kalimantan Utara & 0.1065 & 0.1093 & 0.1036 & 0.1000 \\
\hline
\end{tabular}

\section{B. Metode Back-propaagtion}

Back-propagation merupakan algoritma sistematik untuk pelatihan multilayer JST dengan melakukan pembelajaran untuk mengurangi tingkat error dengan penyesuaian bobot $(\mathrm{w})$ berdasarkan perbedaan keluaran (output) dan tujuan yang diinginkan [12]. Backpropagation menggunakan beberapa level lapisan. Masingmasing lapisan tersebut sebagai berikut:

a) Input layer - lapisan yang mentransfer data ke sistem pada lapisan berikutnya untuk diproses nanti.

b) Output layer - lapisan terakhir dari neuron yang menghasilkan output.

c) Hidden layer - lapisan antara input dan output yang memiliki nilai bobot untuk menghasilkan output melalui fungsi aktivasi [20].

Dalam algoritma back-propagation digunakan fungsi aktivasi sigmoid biner, karena output yang diharapkan bernilai [0 1]. Berikut adalah gambar jaringan arsitektur algoritma back-propagation seperti yang ditunjukkan pada Gambar 2.

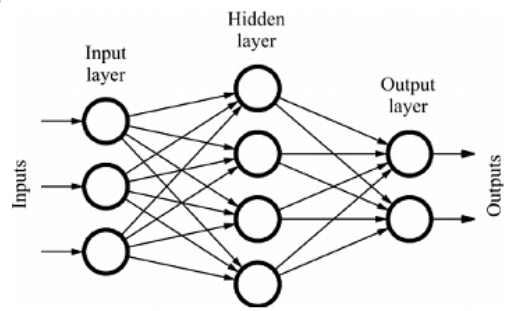

Gambar. 2 Jaringan arsitektur algoritma back-propagation

Berikut adalah langkah-langkah penyelesaian algoritma back-propagation yang dibuat dalam flowchat seperti yang ditunjukkan Gambar 3.

\section{Pengukuran hasil simulasi peramalan}

Prediksi pengukuran metode bertujuan untuk mendapatkan nilai terbaik antara nilai asli dan nilai prediksi. Dalam hal ini terdapat beberapa metode statistik untuk mengukur model prediksi seperti normalize mean square error (NMSE), root mean squared error (RMSE), mean square error (MSE) dan mean absolute error (MAE).
Metode pengukuran yang digunakan pada penelitian adalah MSE dengan formula

$M S E=\frac{\sum_{t=1}^{n}(A t-F t)^{2}}{n}$

Dimana At merupakan nilai observasi data; $(\mathrm{At}-\mathrm{Ft})^{2}$ merupakan nilai hasil peramalan; $\mathrm{n}$ merupakan nilai dari jumlah siswa mengulang.

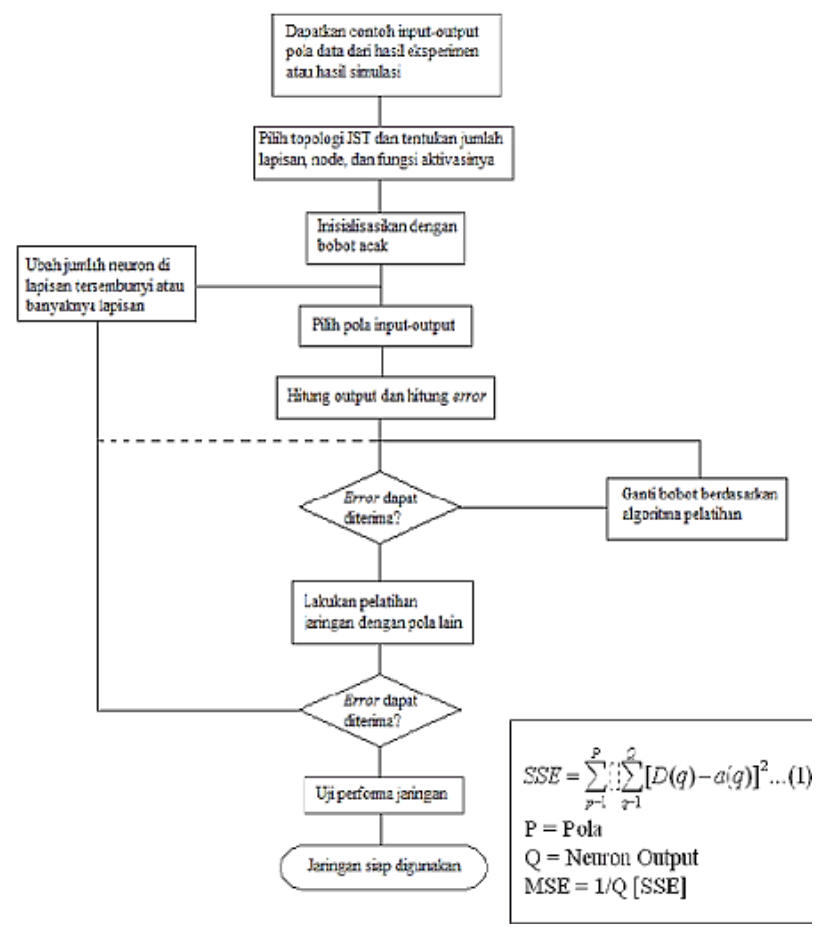

Gambar. 3 Flowchart Algoritma Back-propagation

\section{HASIL DAN PEMBAHASAN}

Sebelum dilakukan proses pelatihan dan pengujian pada serangkaian model arsitektur back-propagation, terlebih dahulu melakukan penetapan input dan output. Dimana yang menjadi variabel input adalah total dari jumlah siswa mengulang berdasarkan provinisi untuk setiap tahun ajaran (Tabel 5) dan variabel output adalah penetapan model arsitektur terbaik pada kasus jumlah siswa mengulang dengan cara menentukan tingkat error dari suatu target. Semakin kecil nilai error maka pola arsitektur terbaik semakin baik dengan range $(0,001$ - 0,02). Dalam penentuan model arsitektur terbaik, proses dibagi dua tahap yakni tahapan pelatihan model dan tahapan pengujian model. Model yang diuji pada penelitian ini adalah 2-5-1; 2-10-1; 2-15-1 dan 2-20-1 dengan menggunakan bantuan software modeling MATLAB R2021a. Tahapan tersebut menggunakan data yang sudah dinormalisasi (Tabel 6) dimana tahapan pelatihan menggunakan data (input: 2016/2017 (x1); 2017/2018 (x2) dan output: 2018/2019 (Y)) serta tahapan pengujian menggunakan data (input: 2017/2018 (x1); 2018/2019 (x2) dan output: 2019/2020 (Y)) seperti yang ditunjukkan pada Tabel 7 dan 8 . 
TABEL VII

DATA PELATIHAN

\begin{tabular}{|c|l|c|c|c|}
\hline No & \multicolumn{1}{|c|}{ Provinsi } & $\begin{array}{c}\mathbf{2 0 1 6 - 2 0 1 7} \\
(\mathbf{X 1})\end{array}$ & $\begin{array}{c}\mathbf{2 0 1 7 - 2 0 1 8} \\
\text { (X2) }\end{array}$ & $\begin{array}{c}\mathbf{2 0 1 8 - 2 0 1 9} \\
(\mathbf{Y})\end{array}$ \\
\hline 1 & Prov. D.K.I Jakarta & 0.1511 & 0.1515 & 0.1578 \\
\hline 2 & Prov. Jawa Barat & 0.3789 & 0.3541 & 0.3346 \\
\hline 3 & Prov. Jawa Tengah & 0.8958 & 0.9000 & 0.8055 \\
\hline 4 & Prov. D.I. Yogyakarta & 0.1316 & 0.1247 & 0.1195 \\
\hline 5 & Prov. Jawa Timur & 0.5011 & 0.4961 & 0.4354 \\
\hline 6 & Prov. Aceh & 0.1610 & 0.1647 & 0.1570 \\
\hline 7 & Prov. Sumatera Utara & 0.3452 & 0.3306 & 0.3118 \\
\hline 8 & Prov. Sumatera Barat & 0.4006 & 0.4071 & 0.3856 \\
\hline 9 & Prov. Riau & 0.2791 & 0.2726 & 0.2704 \\
\hline 10 & Prov. Jambi & 0.1731 & 0.1728 & 0.1701 \\
\hline 11 & Prov. Sumatera Selatan & 0.3156 & 0.3346 & 0.3377 \\
\hline 12 & Prov. Lampung & 0.2570 & 0.2587 & 0.2413 \\
\hline 13 & Prov. Kalimantan Barat & 0.4576 & 0.4765 & 0.4453 \\
\hline 14 & Prov. Kalimantan Tengah & 0.1739 & 0.1870 & 0.1800 \\
\hline 15 & Prov. Kalimantan Selatan & 0.2277 & 0.2275 & 0.2142 \\
\hline 16 & Prov. Kalimantan Timur & 0.1641 & 0.1771 & 0.1664 \\
\hline 17 & Prov. Sulawesi Utara & 0.1168 & 0.1248 & 0.1288 \\
\hline 18 & Prov. Sulawesi Tengah & 0.1880 & 0.1960 & 0.1790 \\
\hline 19 & Prov. Sulawesi Selatan & 0.2631 & 0.2593 & 0.2336 \\
\hline 20 & Prov. Sulawesi Tenggara & 0.1767 & 0.1730 & 0.1646 \\
\hline 21 & Prov. Maluku & 0.1498 & 0.1612 & 0.1492 \\
\hline 22 & Prov. Bali & 0.1181 & 0.1149 & 0.1103 \\
\hline 23 & Prov. Nusa Tenggara Barat & 0.1817 & 0.1927 & 0.1777 \\
\hline 24 & Prov. Nusa Tenggara Timur & 0.5626 & 0.5747 & 0.5307 \\
\hline 25 & Prov. Papua & 0.2703 & 0.3368 & 0.3670 \\
\hline 26 & Prov. Bengkulu & 0.1491 & 0.1490 & 0.1463 \\
\hline 27 & Prov. Maluku Utara & 0.1263 & 0.1271 & 0.1327 \\
\hline 28 & Prov. Banten & 0.2434 & 0.2299 & 0.2136 \\
\hline 29 & Prov. Kep. Bangka Belitung & 0.1539 & 0.1557 & 0.1536 \\
\hline 30 & Prov. Gorontalo & 0.1533 & 0.1588 & 0.1454 \\
\hline 31 & Prov. Kepulauan Riau & 0.1246 & 0.1262 & 0.1231 \\
\hline 32 & Prov. Papua Barat & 0.1482 & 0.1760 & 0.1827 \\
\hline 33 & Prov. Sulawesi Barat & 0.1236 & 0.1296 & 0.1255 \\
\hline 34 & Prov. Kalimantan Utara & 0.1065 & 0.1093 & 0.1036 \\
\hline & & & & \\
\hline
\end{tabular}

TABEL VIII

DATA PENGUJian

\begin{tabular}{|c|l|c|c|r|}
\hline No & \multicolumn{1}{|c|}{ Provinsi } & $\begin{array}{c}\mathbf{2 0 1 7 - 2 0 1 8} \\
(\mathbf{X 1})\end{array}$ & $\begin{array}{c}\mathbf{2 0 1 8 - 2 0 1 9} \\
(\mathbf{X 2})\end{array}$ & $\begin{array}{c}\mathbf{2 0 1 9 -} \\
\mathbf{2 0 2 0}(\mathbf{Y})\end{array}$ \\
\hline 1 & Prov. D.K.I Jakarta & 0.1515 & 0.1578 & 0.1478 \\
\hline 2 & Prov. Jawa Barat & 0.3541 & 0.3346 & 0.2895 \\
\hline 3 & Prov. Jawa Tengah & 0.9000 & 0.8055 & 0.6368 \\
\hline 4 & Prov. D.I. Yogyakarta & 0.1247 & 0.1195 & 0.1117 \\
\hline 5 & Prov. Jawa Timur & 0.4961 & 0.4354 & 0.3464 \\
\hline 6 & Prov. Aceh & 0.1647 & 0.1570 & 0.1467 \\
\hline 7 & Prov. Sumatera Utara & 0.3306 & 0.3118 & 0.2821 \\
\hline 8 & Prov. Sumatera Barat & 0.4071 & 0.3856 & 0.3266 \\
\hline 9 & Prov. Riau & 0.2726 & 0.2704 & 0.2446 \\
\hline 10 & Prov. Jambi & 0.1728 & 0.1701 & 0.1565 \\
\hline 11 & Prov. Sumatera Selatan & 0.3346 & 0.3377 & 0.2914 \\
\hline 12 & Prov. Lampung & 0.2587 & 0.2413 & 0.2078 \\
\hline 13 & Prov. Kalimantan Barat & 0.4765 & 0.4453 & 0.4015 \\
\hline 14 & Prov. Kalimantan Tengah & 0.1870 & 0.1800 & 0.1677 \\
\hline 15 & Prov. Kalimantan Selatan & 0.2275 & 0.2142 & 0.1945 \\
\hline 16 & Prov. Kalimantan Timur & 0.1771 & 0.1664 & 0.1493 \\
\hline 17 & Prov. Sulawesi Utara & 0.1248 & 0.1288 & 0.1213 \\
\hline 18 & Prov. Sulawesi Tengah & 0.1960 & 0.1790 & 0.1573 \\
\hline 19 & Prov. Sulawesi Selatan & 0.2593 & 0.2336 & 0.2088 \\
\hline 20 & Prov. Sulawesi Tenggara & 0.1730 & 0.1646 & 0.1461 \\
\hline 21 & Prov. Maluku & 0.1612 & 0.1492 & 0.1414 \\
\hline 22 & Prov. Bali & 0.1149 & 0.1103 & 0.1041 \\
\hline 23 & Prov. Nusa Tenggara Barat & 0.1927 & 0.1777 & 0.1588 \\
\hline 24 & Prov. Nusa Tenggara Timur & 0.5747 & 0.5307 & 0.4333 \\
\hline 25 & Prov. Papua & 0.3368 & 0.3670 & 0.3234 \\
\hline 26 & Prov. Bengkulu & 0.1490 & 0.1463 & 0.1384 \\
\hline 27 & Prov. Maluku Utara & 0.1271 & 0.1327 & 0.1206 \\
\hline 28 & Prov. Banten & 0.2299 & 0.2136 & 0.1888 \\
\hline 29 & Prov. Kep. Bangka Belitung & 0.1557 & 0.1536 & 0.1390 \\
\hline 30 & Prov. Gorontalo & 0.1588 & 0.1454 & 0.1330 \\
\hline 31 & Prov. Kepulauan Riau & 0.1262 & 0.1231 & 0.1196 \\
\hline 32 & Prov. Papua Barat & 0.1760 & 0.1827 & 0.1721 \\
\hline 33 & Prov. Sulawesi Barat & 0.1296 & 0.1255 & 0.1197 \\
\hline 34 & Prov. Kalimantan Utara & 0.1093 & 0.1036 & 0.1000 \\
\hline & & & & \\
\hline
\end{tabular}

Kemudian melakukan pelatihan dilakukan beberapa pemilihan nilai parameter untuk memperoleh hasil yang optimal. Adapun nilai parameter yang digunakan dapat dilihat pada Gambar 4.

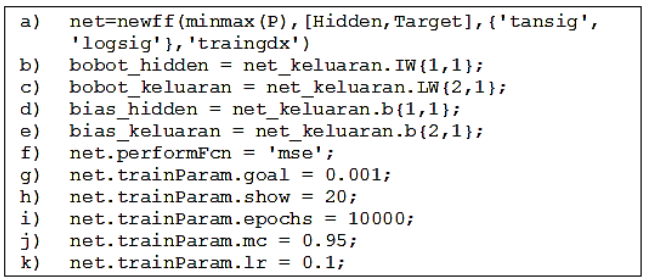

Gambar. 4 Nilai parameter

Dalam eksperimen ini, arsitektur back-propagation yang digunakan terdiri dari satu lapisan hidden layer $(5 ; 15 ; 15$; 20) dengan fungsi aktivasi fungsi aktivasi 'tansig' (input ke hidden layer) dan 'logsig' (hidden ke output layer). Sedangkan algoritma pelatihan yang digunakan untuk semua arsitektur adalah 'traingdx'. Dalam pengujian ini, metode statistik MSE digunakan untuk membandingkan nilai asli dan nilai hasil peramalan.

TABEL IX

Hasil Pelatihan Algoritma BaCK-Propagation

\begin{tabular}{|l|l|r|r|r|}
\cline { 3 - 5 } \multicolumn{2}{c|}{} & \multicolumn{3}{c|}{ Pelatihan } \\
\hline \multirow{2}{*}{ No } & $\begin{array}{c}\text { Model } \\
\text { Arsitektur }\end{array}$ & $\begin{array}{c}\text { Mean Square } \\
\text { Error (MSE) }\end{array}$ & $\begin{array}{c}\text { Koefisien } \\
\text { korelasi (R) }\end{array}$ & Epoch \\
\hline 1 & $2-5-1$ & 0.00099424 & 0.97813 & 132 \\
\hline 2 & $2-10-1$ & 0.00099299 & 0.976972 & 81 \\
\hline 3 & $2-15-1$ & 0.00097013 & 0.97817 & 87 \\
\hline 4 & $2-20-1$ & 0.00099062 & 0.97873 & 135 \\
\hline
\end{tabular}

TABEL X

Hasil Pengujian Algoritma BaCK-Propagation

\begin{tabular}{|l|l|r|r|r|}
\cline { 3 - 5 } \multicolumn{2}{l|}{} & \multicolumn{3}{c|}{ Pengujian } \\
\hline No & $\begin{array}{c}\text { Model } \\
\text { Arsitektur }\end{array}$ & $\begin{array}{c}\text { Mean Square } \\
\text { Error (MSE) }\end{array}$ & $\begin{array}{c}\text { Koefisien } \\
\text { korelasi (R) }\end{array}$ & Akurasi \\
\hline 1 & $2-5-1$ & 0.0010664 & 0.96035 & $68 \%$ \\
\hline 2 & $2-10-1$ & 0.001325 & 0.96589 & $85 \%$ \\
\hline 3 & $2-15-1$ & 0.00069132 & 0.9799 & $76 \%$ \\
\hline 4 & $2-20-1$ & 0.002116 & 0.98417 & $74 \%$ \\
\hline
\end{tabular}

Dari Tabel 9 dan 10 dijelaskan bahwa model arsitektur 2-10-1 merupakan model terbaik dengan akurasi pengujian sebersar $80 \%$. Berikut hasil lengkap dari model arsitektur terbaik menggunakan software MATLAB R2021a seperti yang ditunjukkan Gambar 5 dan 6 berikut.

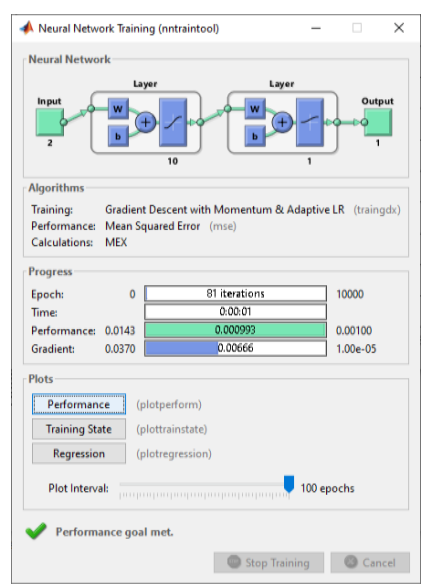

Gambar. 5 GUI dari pelatihan model arsitektur terbaik dengan algortima back-propagation 


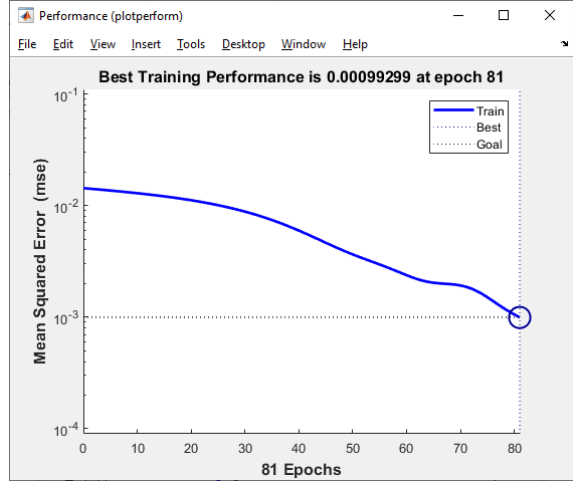

Gambar. 6 Hasil pelatihan model arsitektur terbaik dengan algortima back-propagation dimana error goal (MSE) sebesar 0.00099299 dicapai pada epoch yang ke-81

Pada Gambar 5 tampilan tersebut ditunjukkan bahwa target error (mse) tercapai pada epoch ke-81. Error (mse) yang dihasilkan pada setiap epoch dapat dilihat dengan meng-klik tombol 'performance' sehingga muncul tampilan seperti yang ditunjukkan pada Gambar 6 . Sedangkan koefisien korelasi hasil pelatihan dapat dilihat dengan meng-klik tombol 'regression' sehingga muncul tampilan seperti yang ditunjukkan pada Gambar 7 .

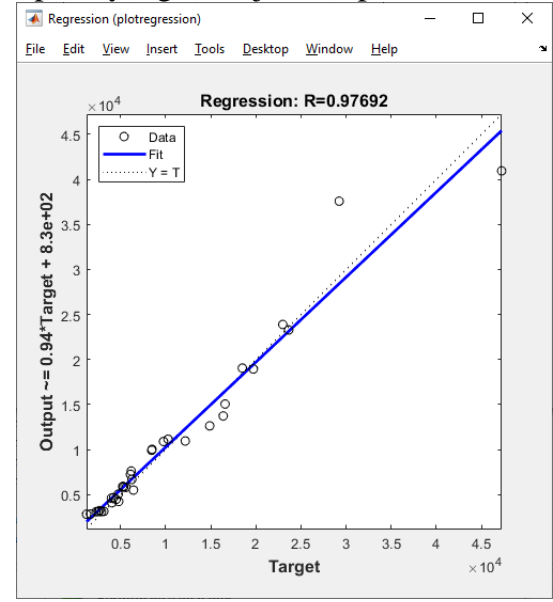

Gambar. 7 Koefisien korelasi R yang dihasilkan adalah sebesar 0,97692 dengan algortima back-propagation

Pada Gambar 7 nilai koefisien korelasi sebesar 0.97692 menunjukkan bahwa akurasi hasil proses pelatihan sangat baik. Berikut adalah grafik keluaran JST vs target seperti yang ditunjukkan pada Gambar 8.

Berdasarkan Gambar 8 pada nilai koefisien korelasi dan nilai MSE (Mean Square Error) yang diperoleh pada proses pelatihan tersebut sangat baik. Berikut hasil koefisien korelasi hasil pengujian dan perbandingan nilai luaran grafik keluaran JST vs target hasil pengujian seperti yang ditunjukkan pada Gambar 9 dan 10 .

Pada Gambar 10 dijelaskan bahwa nilai koefisien korelasi dan nilai MSE yang dihasilkan pada proses pengujian menunjukkan bahwa algoritma backpropagation cukup baik untuk meramal jumlah siswa mengulang. Berikut adalah perbandingan dari data target dan error yang dihasilkan oleh model arsitektur terbaik 210-1 seperti yang ditunjukkan pada Tabel 11.

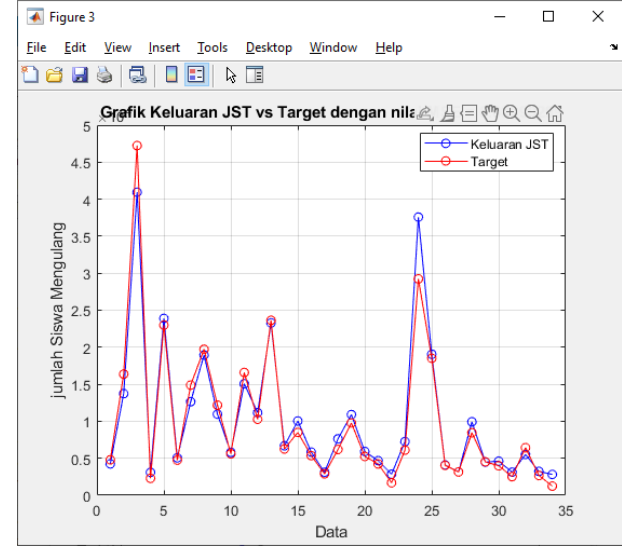

Gambar. 8 Hasil nilai koefisien korelasi dan nilai yang diperoleh pada proses pelatihan dalam meramal jumlah siswa mengulang adalah sangat baik.

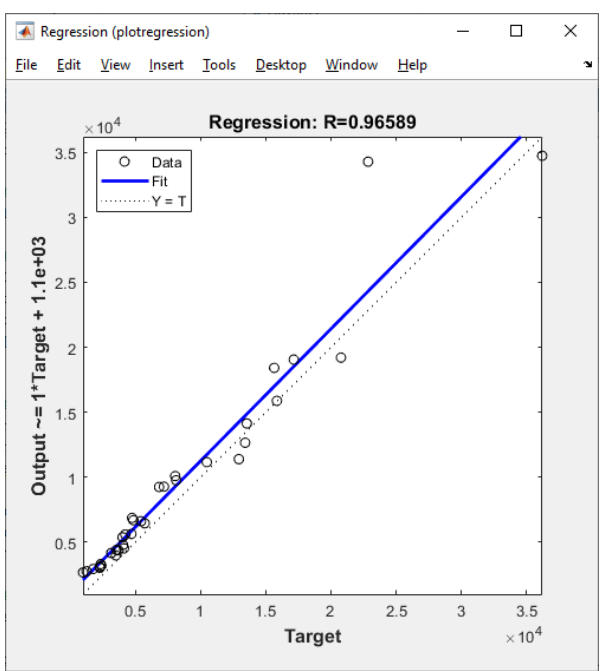

Gambar. 9 Hasil proses pengujian jaringan yang menghasilkan koefisien korelasi sebesar 0,96589 pada model arsitektur 2-10-1

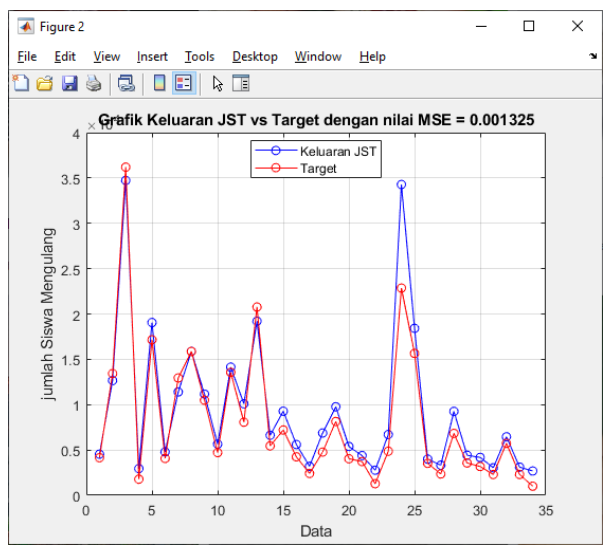

Gambar. 10 Hasil pengujiandari garik keluaran JST dan nilai MSE

TABEL X

PERBANDINGAN DATA TARGET DAN ERROR PADA MODEL ARSITEKTUR TERBAIK

\begin{tabular}{|c|c|c|c|c|c|}
\hline No & Provinsi & Target & Error & SSE & Prediksi \\
\hline 1 & Prov. D.K.I Jakarta & 0.1478 & 0.0060 & 0.00003545 & 1 \\
\hline
\end{tabular}




\begin{tabular}{|c|l|c|c|c|c|}
\hline No & \multicolumn{1}{|c|}{ Provinsi } & Target & Error & SSE & Prediksi \\
\hline 2 & Prov. Jawa Barat & 0.2895 & -0.0117 & 0.00013747 & 1 \\
\hline 3 & Prov. Jawa Tengah & 0.6368 & -0.0223 & 0.00049941 & 1 \\
\hline 4 & Prov. D.I. Yogyakarta & 0.1117 & 0.0178 & 0.00031832 & 1 \\
\hline 5 & Prov. Jawa Timur & 0.3464 & 0.0290 & 0.00084118 & 1 \\
\hline 6 & Prov. Aceh & 0.1467 & 0.0110 & 0.00012080 & 1 \\
\hline 7 & Prov. Sumatera Utara & 0.2821 & -0.0236 & 0.00055835 & 1 \\
\hline 8 & Prov. Sumatera Barat & 0.3266 & 0.0003 & 0.00000009 & 1 \\
\hline 9 & Prov. Riau & 0.2446 & 0.0103 & 0.00010596 & 1 \\
\hline 10 & Prov. Jambi & 0.1565 & 0.0143 & 0.00020340 & 1 \\
\hline 11 & Prov. Sumatera Selatan & 0.2914 & 0.0089 & 0.00007976 & 1 \\
\hline 12 & Prov. Lampung & 0.2078 & 0.0308 & 0.00095088 & 0 \\
\hline 13 & Prov. Kalimantan Barat & 0.4015 & -0.0238 & 0.00056806 & 1 \\
\hline 14 & Prov. Kalimantan Tengah & 0.1677 & 0.0179 & 0.00031946 & 1 \\
\hline 15 & Prov. Kalimantan Selatan & 0.1945 & 0.0317 & 0.00100293 & 0 \\
\hline 16 & Prov. Kalimantan Timur & 0.1493 & 0.0208 & 0.00043299 & 1 \\
\hline 17 & Prov. Sulawesi Utara & 0.1213 & 0.0121 & 0.00014573 & 1 \\
\hline 18 & Prov. Sulawesi Tengah & 0.1573 & 0.0322 & 0.00103537 & 0 \\
\hline 19 & Prov. Sulawesi Selatan & 0.2088 & 0.0248 & 0.00061560 & 1 \\
\hline 20 & Prov. Sulawesi Tenggara & 0.1461 & 0.0207 & 0.00042653 & 1 \\
\hline 21 & Prov. Maluku & 0.1414 & 0.0100 & 0.00010002 & 1 \\
\hline 22 & Prov. Bali & 0.1041 & 0.0227 & 0.00051682 & 1 \\
\hline 23 & Prov. Nusa Tenggara Barat & 0.1588 & 0.0280 & 0.00078535 & 1 \\
\hline 24 & Prov. Nusa Tenggara Timur & 0.4333 & 0.1743 & 0.03037607 & 1 \\
\hline 25 & Prov. Papua & 0.3234 & 0.0422 & 0.00178103 & 0 \\
\hline 26 & Prov. Bengkulu & 0.1384 & 0.0072 & 0.00005154 & 1 \\
\hline 27 & Prov. Maluku Utara & 0.1206 & 0.0147 & 0.00021693 & 1 \\
\hline 28 & Prov. Banten & 0.1888 & 0.0370 & 0.00136763 & 0 \\
\hline 29 & Prov. Kepulauan Bangka & 0.1390 & 0.0130 & 0.00016779 & 1 \\
\hline 30 & Prov. Gorontalo & 0.1330 & 0.0153 & 0.00023378 & 1 \\
\hline 31 & Prov. Kepulauan Riau & 0.1196 & 0.0113 & 0.00012874 & 1 \\
\hline 32 & Prov. Papua Barat & 0.1721 & 0.0111 & 0.00012288 & 1 \\
\hline 33 & Prov. Sulawesi Barat & 0.1197 & 0.0123 & 0.00015145 & 1 \\
\hline 34 & Prov. Kalimantan Utara & 0.1000 & 0.0255 & 0.00065229 & 1 \\
\hline & & & MSE & $\mathbf{0 . 0 0 1 3 2 5 0 0}$ & $\mathbf{8 5 \%}$ \\
\cline { 4 - 6 } & & & & & \\
& & & & & 1 \\
\hline
\end{tabular}

\section{KESIMPULAN}

Paper ini mempresentasikan penerapan model berbasis sistem kecerdasan buatan dalam melakukan peramalan jumlah siswa mengulang berdasarkan provinsi pada jenjang Sekolah Dasar. Metode back-propagation yang menjadi solusi dari permasalahan tersebut dapat menghasilkan model arsitektur yang dapat digunakan dalam melakukan peramalan pada jumlah siswa mengulang sehingga hasil dari peramalan dapat digunakan untuk membuat analisis kebijakan. Fakta baru menyebutkan bahwa akurasi sangat tergantung terhadap banyaknya data dalam melakukan peramalan. Kedepan penelitian ini dapat dikombinasikan dengan algoritma lain untuk mengoptimalisasi hasil seperti Particle Swarm Optimization (PSO) dan algoritma genetika (GA).

\section{REFERENSI}

[1] B. P. D. P. D. P. K. P. D. Kebudayaan, Potret mengulang kelas di Sekolah Dasar. Jakarta: Pusat Penelitian Kebijakan, Badan Penelitian dan Pengembangan dan Perbukuan, Kementerian Pendidikan dan Kebudayaan Redaksi:, 2020.

[2] Herwanto, "Wajib Belajar (Wajar) Sembilan Tahun Dalam Perspektif Peningkatan Mutu Pendidikan Dasar," Perspektif Ilmu Pendidikan, vol. 16, no. 8, pp. 77-86, 2007.

[3] S. Suryana, Permasalahan Mutu Pendidikan Dalam Perspektif Pembangunan Pendidikan, vol. 2, no. 1. 2017.

[4] H. Haviluddin, Z. Arifin, A. H. Kridalaksana, and D. Cahyadi, "Prediksi Kedatangan Turis Asing ke Indonesia Menggunakan Backpropagation Neural Networks," Jurnal Teknologi dan Sistem Komputer, vol. 4, no. 4, p. 485, 2016, doi: 10.14710/jtsiskom.4.4.2016.485-490.

[5] X. Sun, W. Sun, J. Wang, Y. Zhang, and Y. Gao, "Using a GreyeMarkov model optimized by Cuckoo search algorithm to forecast the annual foreign tourist arrivals to China," Tourism Management, vol. 52, pp. 369-379, 2016
[6] H. Hassani, A. Webster, E. S. Silva, and S. Heravi, "Forecasting U.S. Tourist arrivals using optimal Singular Spectrum Analysis," Tourism Management, vol. 46, pp. 322-335, 2015.

[7] W. Lijuan and C. Guohua, "Seasonal SVR with FOA algorithm for single-step and multi-step ahead forecasting in monthly inbound tourist flow," Knowledge-Based Systems, vol. 110, 2016.

[8] B. Fachri, A. P. Windarto, and I. Parinduri, "Penerapan Backpropagation dan Analisis Sensitivitas pada Prediksi Indikator Terpenting Perusahaan Listrik," Jurnal Edukasi dan Penelitian Informatika (JEPIN), vol. 5, no. 2, p. 202, 2019, doi: 10.26418/jp.v5i2.31650.

[9] I. A. R. Simbolon, F. Yatussa'ada, and A. Wanto, "Penerapan Algoritma Backpropagation dalam Memprediksi Persentase Penduduk Buta Huruf di Indonesia," Jurnal Informatika Upgris, vol. 4, no. 2, 2019, doi: 10.26877/jiu.v4i2.2423.

[10] Y. Aprizal, R. I. Zainal, and A. Afriyudi, "Perbandingan Metode Backpropagation dan Learning Vector Quantization (LVQ) Dalam Menggali Potensi Mahasiswa Baru di STMIK PalComTech," MATRIK : Jurnal Manajemen, Teknik Informatika dan Rekayasa Komputer, vol. 18, no. 2, pp. 294-301, 2019, doi: 10.30812/matrik.v18i2.387.

[11] B. Poerwanto and F. Fajriani, "Resilient Backpropagation Neural Network on Prediction of Poverty Levels in South Sulawesi," MATRIK : Jurnal Manajemen, Teknik Informatika dan Rekayasa Komputer, vol. 20, no. 1, pp. 11-18, 2020, doi: 10.30812/matrik.v20i1.726.

[12] Budiharjo, T. Soemartono, A. P. Windarto, and T. Herawan, "Predicting School Participation in Indonesia using BackPropagation Algorithm Model," International Journal of Control and Automation, vol. 11, no. 11, pp. 57-68, 2018.

[13] A. P. Windarto, J. Na, and A. Wanto, "Bagian 2 : Model Arsitektur Neural Network dengan Kombinasi K- Medoids dan Backpropagation pada kasus Pandemi COVID-19 di Indonesia," Jurnal Media Informatika Budidarma, vol. 4, no. 4, pp. 1175-1180, 2020, doi: 10.30865/mib.v4i4.2505.

[14] B. Febriadi, Z. Zamzami, Y. Yunefri, and A. Wanto, "Bipola function in backpropagation algorithm in predicting Indonesia's coal exports by major destination countries," IOP Conference Series: Materials Science and Engineering, vol. 420, no. 1, 2018, doi: 10.1088/1757-899X/420/1/012087.

[15] Budiharjo, T. Soemartono, A. P. Windarto, and T. Herawan, "Predicting tuition fee payment problem using backpropagation neural network model," International Journal of Advanced Science and Technology, vol. 120, pp. 85-96, 2018, doi: 10.14257/ijast.2018.120.07

[16] Sumijan, A. P. Windarto, A. Muhammad, and Budiharjo, "Implementation of neural networks in predicting the understanding level of students subject," International Journal of Software Engineering and its Applications, vol. 10, no. 10, pp. 189204, 2016, doi: 10.14257/ijseia.2016.10.10.18.

[17] S. Sunardi, A. Yudhana, and G. Z. Muflih, "Sistem Prediksi Curah Hujan Bulanan Menggunakan Jaringan Saraf Tiruan Backpropagation," Jurnal Sistem Informasi Bisnis, vol. 10, no. 2, pp. 155-162, 2020, [Online]. Available: http://ejournal.undip.ac.id/index.php/jsinbis.

[18] P. Li and Q. Zhang, "Face Recognition Algorithm Comparison based on Backpropagation Neural Network," Journal of Physics: Conference Series, vol. 1865, no. 4, 2021, doi: 10.1088/17426596/1865/4/042058

[19] R. Ruslan, L. Laome, I. Usman, and E. W. Harisa, "Electricity Consumption Modelling in Kendari using the Backpropagation Method on the Artificial Neural Network," Journal of Physics: Conference Series, vol. 1863, no. 1, 2021, doi: 10.1088/1742$6596 / 1863 / 1 / 012076$

[20] S. Nurhasanah, I. Ranggadara, I. Prihandi, and A. Ratnasari, "Backpropagation neural network for predict sugarcane stock availability," International Journal of Advanced Trends in Computer Science and Engineering, vol. 9, no. 5, pp. 8279-8284, 2020, doi: 10.30534/ijatcse/2020/197952020. 